\title{
Minimum Daily Light Integral for Growing High-quality Coleus
}

\author{
Katherine F. Garland ${ }^{1,2,5}$, Stephanie E. Burnett ${ }^{1}$, Lois B. Stack ${ }^{1,3}$, \\ and Donglin Zhang $^{1,4}$
}

AdDitional INDEX WORDs. foliage color, lighting, DLI, irradiance, Solenostemon

Summary. Coleus (Solenostemon scutellarioides) traditionally has been recommended as a shade plant, but many cultivars are also suitable for full sun. In regions of the country where light limits growth and photosynthesis, supplemental lights are used to increase daily light integral (DLI). Understanding the minimum DLI necessary to produce coleus would minimize supplemental lighting use, reducing costs and improving production sustainability. 'Kong Red' and 'Wizard Coral Sunrise' coleus were grown in a greenhouse under a 12-hour photoperiod and a mean DLI of $2.9,3.8,5.8$, or $10.0 \mathrm{~mol} \cdot \mathrm{m}^{-2} \cdot \mathrm{d}^{-1}$ to determine the lowest light level needed to produce high-quality plants. After 8 weeks, both cultivars had a 4.2 -fold increase in shoot dry weight as DLI increased from 2.9 to $10.0 \mathrm{~mol} \cdot \mathrm{m}^{-2} \cdot \mathrm{d}^{-1}$. Plants grown under $10.0 \mathrm{~mol} \cdot \mathrm{m}^{-2} \cdot \mathrm{d}^{-1}$ were $22 \%$ to $25 \%$ taller and $18 \%$ to $21 \%$ wider compared with those grown under $2.9 \mathrm{~mol} \cdot \mathrm{m}^{-2} \cdot \mathrm{d}^{-1}$. 'Kong Red' had 3.6 times as many branches and 'Wizard Coral Sunrise' had over twice as many branches when grown under $10.0 \mathrm{~mol} \cdot \mathrm{m}^{-2} \cdot \mathrm{d}^{-1}$ compared with those grown under the lowest DLI. Leaf counts for both cultivars were $64 \%$ greater when grown under the highest DLI compared with those produced under the lowest DLI; leaf area for both cultivars was also positively correlated with DLI. Leaves of both cultivars had significantly more green area (i.e., less variegation) when grown under lower DLIs. Overall, both cultivars exhibited a more dense growth habit and greater degree of variegation when grown under the highest DLI. Therefore, we recommend growing 'Kong Red' and 'Wizard Coral Sunrise' coleus under a minimum DLI of $10.0 \mathrm{~mol} \cdot \mathrm{m}^{-2} \cdot \mathrm{d}^{-1}$.

$\mathrm{G}$ reenhouse production of coleus generally occurs between the months of February and May in the United States to coincide with spring bedding plant sales. Mean outdoor daily light integrals (DLIs) at this time of year in the northeastern United States range from 15 to 40 $\mathrm{mol} \cdot \mathrm{m}^{-2} \cdot \mathrm{d}^{-1}$ compared with 25 to $60 \mathrm{~mol} \cdot \mathrm{m}^{-2} \cdot \mathrm{d}^{-1}$ in the southwestern

Maine Agriculture and Forestry Experiment Station Publication number 3132 .

The authors greatly appreciate the Maine Agricultural Center and New England Floriculture for funding this research project.

The authors greatly appreciate Ball Horticultural (West Chicago, IL) for donating seed; Conrad Fafard (Anderson, SC) for donating media; and Michael Day, Ellen Fisher, Bradley Libby, and Svoboda Pennisi for providing advice and assistance. We thank Michael Day and Renae Moran for reviewing an early draft of this article.

${ }^{1}$ Department of Plant, Soil, and Environmental Sciences, University of Maine, 5722 Deering Hall, Orono, ME 04469

${ }^{2}$ University of Maine Cooperative Extension, 307 Maine Avenue, Bangor, ME 04401

${ }^{3}$ University of Maine Cooperative Extension, 495 College Avenue, Orono, ME 04473

${ }^{4}$ Guest Professor, Central South University of Forestry and Technology, Changsha, China

${ }^{5}$ Corresponding author. E-mail: Katherine.garland@ maine.edu.
United States (Korczynski et al., 2002). Mechanical impedance of light by glazing materials and greenhouse support structures reduces transmission of light into a greenhouse as much as $50 \%$ (Fisher and Runkle, 2004). Thus, the actual DLI in greenhouses ranges from 7.5 to 20 $\mathrm{mol} \cdot \mathrm{m}^{-2} \cdot \mathrm{d}^{-1}$ in the northeastern United States to 12.5 to $30 \mathrm{~mol} \cdot \mathrm{m}^{-2} \cdot \mathrm{d}^{-1}$ in southwestern United States. It is often necessary to provide supplemental lighting during the spring production season, particularly for growers in the northeastern United States. For example, minimum DLI recommendations for high light-adapted crops such as yarrow (Achillea millefolium), gaura (Gaura lindheimeri), and english lavender (Lavandula angustifolia) range from 15 to $20 \mathrm{~mol} \cdot \mathrm{m}^{-2} \cdot \mathrm{d}^{-1}$ (Fausey et al., 2005).

Some bedding plants, such as coleus, may tolerate lower light levels compared with yarrow, gaura, and english lavender. Verkbert et al. (2004) recommend growing coleus at a minimum DLI of $9 \mathrm{~mol} \cdot \mathrm{m}^{-2} \cdot \mathrm{d}^{-1}$ and no more than $18 \mathrm{~mol} \cdot \mathrm{m}^{-2} \cdot \mathrm{d}^{-1}$ for highquality plants. However, light tolerance varies among coleus cultivars; some cultivars are best grown in shade, while others would grow optimally in full sun (Armitage, 2001; Rogers and Hartlage, 2008; Stack, 2009). Stack (2009) conducted a field trial to assess the performance of 79 cultivars of coleus under northern New England full sun conditions and found that over half of the cultivars were good candidates for full sun, while the remaining cultivars were better suited for shaded conditions. Actual DLIs were not recorded in this study. The variation in sun tolerance among cultivars in the field suggests that there may also be a variation in light requirements in the greenhouse. Determining the lowest light levels needed for producing coleus may reduce the need for supplemental lighting, thus reducing energy use and increasing production sustainability.

Daily light integral has diverse effects on morphology, which would be important to consider when determining the lowest light levels appropriate for growing coleus. Shoot dry weight of cockscomb (Celosia argentea var. plumose 'Gloria Mix'), impatiens (Impatiens walleriana 'Accent Red'), and french marigold (Tagetes patula 'Bonanza Yellow'), and total dry weight (shoot and root) of wax begonia (Begonia semperflorens-cultorum 'Cocktail Vodka') were greater when plants were grown under $14.4 \mathrm{~mol} \cdot \mathrm{m}^{-2} \cdot \mathrm{d}^{-1}$ compared with those grown under $5.3 \mathrm{~mol} \cdot \mathrm{m}^{-2} \cdot \mathrm{d}^{-1}$ (Nemali and van Iersel, 2004; Pramuk and Runkle, 2005). Fausey et al. (2005)

\begin{tabular}{llll}
\hline $\begin{array}{l}\text { Units } \\
\text { To convert U.S. to SI, } \\
\text { multiply by }\end{array}$ & U.S. unit & SI unit & $\begin{array}{l}\text { To convert SI to U.S., } \\
\text { multiply by }\end{array}$ \\
\hline 29.5735 & $\mathrm{fl} \mathrm{oz}$ & $\mathrm{mL}$ & 0.0338 \\
0.3048 & $\mathrm{ft}$ & $\mathrm{m}$ & 3.2808 \\
3.7854 & gal & $\mathrm{L}$ & 0.2642 \\
2.54 & inch $(\mathrm{es})$ & $\mathrm{cm}$ & 0.3937 \\
6.4516 & inch & $\mathrm{cm}^{2}$ & 0.1550 \\
28.3495 & $\mathrm{Oz}$ & $\mathrm{g}$ & 0.0353 \\
1 & $\mathrm{ppm}$ & $\mathrm{mg} \cdot \mathrm{L}^{-1}$ & 1 \\
$\left({ }^{\circ} \mathrm{F}-32\right) \div 1.8$ & ${ }^{\circ} \mathrm{F}$ & ${ }^{\circ} \mathrm{C}$ & $\left(1.8 \times{ }^{\circ} \mathrm{C}\right)+32$
\end{tabular}


reported that higher DLI resulted in improved visual quality (height, flower color, lateral branching, foliage color) of yarrow, gaura, and english lavender.

Daily light integral can influence leaf variegation in addition to overall crop growth. Coleus is widely used as a foliage plant, and it has uniquely colored foliage with leaves that are either monochromatic or a distinctly variegated combination of two or more colors, including burgundy, green, pink, coral, yellow, orange, and dark purple. Foliage crops including english ivy (Hedera helix 'Gold Heart'), pothos (Epipremnum aureum var. pinnatum), and cast iron plant (Aspidistra elatior 'Variegata') developed less variegation when grown under lower amounts of light (Nam et al., 1997; Pennisi et al., 2005; Stamps, 1995). Conversely, the leaves of variegated cultivars of radiator plant (Peperomia obtusifolia) and dracaena (Dracaena sanderana) have more variegation when plants are grown under lower DLIs (Shen and Seeley, 1983; Vladimirova et al., 1997).

Successful coleus sales rely on a combination of dramatic coloration and dense growth habit. To our knowledge, the lowest light levels required to promote these characteristics in coleus have not been reported. Therefore, the objective of this study was to determine the lowest DLI necessary to produce the marketable coleus crop.

\section{Materials and methods}

'Kong Red' and 'Wizard Coral Sunrise' coleus (Ball Horticultural Co., West Chicago, IL) were selected for this study for the following reasons: 1) their leaf margins were relatively flat, allowing the leaves to be more accurately scanned during variegation analysis; 2) they represented two distinctly different color combinations (i.e., one dark combination and one pastel combination); and 3 ) the cultivars represented two different sun tolerance groups ('Kong Red' = tolerant and 'Wizard Coral Sunrise' $=$ not tolerant) determined in a preliminary field trial that was conducted to assess sunscald in coleus grown in full sun (Stack, 2009). Foliage of 'Kong Red' is characterized by a deep burgundy center with a dark green margin, while 'Wizard Coral Sunrise' has a bright coral center edged with burgundy surrounded by a light green margin.
Seeds of both coleus cultivars were sown in 288 cell plug trays (6.8-mL cell volume) containing a peat-based germination mix (Sun Gro Horticulture, Bellevue, WA) on 11 Aug. 2008. Seedlings were grown on a mist bench until they reached the four-leaf stage. They received continuous liquid fertilization beginning 21 Aug. 2008 using a 75-ppm nitrogen (N) solution $(15 \mathrm{~N}-2.2 \mathrm{P}-12.5 \mathrm{~K}$; Peters Excel 15-5-15 Cal-Mag; Scotts, Marysville, $\mathrm{OH}$ ). Young coleus plants were transplanted into l-gal nursery containers filled with a peat-, bark-, and perlite-based growing mix with starter fertilizer (Fafard 3B; Conrad Fafard, Anderson, SC) on 1 Oct. 2008. After transplanting, continuous liquid fertilization was increased to 150 -ppm $\mathrm{N}$ of the same fertilizer. Average daily temperatures $( \pm \mathrm{SE})$ between 26 Oct. and 26 Nov. 2008 were $20.5 \pm 0.07$ ${ }^{\circ} \mathrm{C}$. Plants were grown in a double-layer polycarbonate greenhouse for the entire experiment and were hand watered as needed after transplanting.

Three shade treatments were provided by square $(2 \times 2 \times 2 \mathrm{ft})$ polyvinyl chloride (PVC) pipe structures covered with a single, double, or triple layer of commercial $30 \%$ shade cloth (K-Pro Supply, Sarasota, FL), respectively. Ambient light treatment plants were grown on the greenhouse benches without a PVC structure over them. Supplemental lighting was provided by $600-W$ high-pressure sodium lights (PL2000; P.L. Light Systems, Beamsville, ON, Canada) mounted above the shade structures from 0800 to $2000 \mathrm{HR}$. Light levels were monitored in each experimental unit using quantum sensors (model QSO-S; Apogee Instruments, Logan, UT) connected to a data logger (CRIOX; Campbell Scientific, Logan, UT). The data logger was programmed to record instantaneous light levels $\left(\mu \mathrm{mol} \cdot \mathrm{m}^{-2} \cdot \mathrm{s}^{-1}\right)$ every $20 \mathrm{~s}$ and average the readings every 5 min throughout the entire investigation. DLIs $\left(\mathrm{mol} \cdot \mathrm{m}^{-2} \cdot \mathrm{d}^{-1}\right)$ were calculated using the mean of the instantaneous light levels throughout the experiment in the following equation:

$$
\begin{aligned}
& \left(\mu \mathrm{mol} \cdot \mathrm{m}^{-2} \cdot \mathrm{s}^{-1} \times 60 \mathrm{~s} \cdot \mathrm{min}^{-1}\right. \\
& \left.\times 60 \mathrm{~min} \cdot \mathrm{h}^{-1} \times 24 \mathrm{~h} \cdot \mathrm{d}^{-1}\right) \\
& \div 1,000,000 \mu \mathrm{mol} \cdot \mathrm{mol}^{-1}
\end{aligned}
$$

DLIs resulting from the four treatments were $2.9,3.8,5.8$, and
$10.0 \mathrm{~mol} \cdot \mathrm{m}^{-2} \cdot \mathrm{d}^{-1}( \pm \mathrm{SE}=0.11,0.02$, 0.17 , and $\left.0.22 \mathrm{~mol} \cdot \mathrm{m}^{-2} \cdot \mathrm{d}^{-1}\right)$ for plants covered with $3,2,1$, or 0 layers of $30 \%$ shade cloth, respectively. Treatments were found to be significantly different according to Fisher's least significant difference in SAS (version 9.1; SAS Institute, Cary, NC).

Total shoot height from the substrate surface to the highest point of the plant and width at widest point were measured weekly throughout the experiment. The study concluded on 26 Nov. 2008 (56 d after transplanting). At this time, final shoot height, plant width, and total leaf count were recorded. Primary and secondary branches were also counted. Branches originating from the main stem were considered primary branches, while those originating from primary branches were considered secondary branches. Primary and secondary branches were counted when they had three or more leaves longer than $1 \mathrm{~cm}$.

Total leaf area of one representative plant of each cultivar from each experimental unit was measured using a leaf area meter (LI-3100A; LICOR Biosciences, Lincoln, NE). The uppermost fully expanded leaf from these representative plants was scanned using a flatbed scanner (ScanJet 5200C; Hewlett-Packard, Palo Alto, CA). Leaf color analysis of the scanned leaves was conducted in Photoshop (CS2 version 9.0; Adobe Systems, San Jose, CA) using the methods described by Li et al. (2007). Tolerance level was set at 20 for all colors with the exception of the coral color in 'Wizard Coral Sunrise' foliage, which was set at 32 because the lower tolerance setting did not capture the entire coral region. Percent leaf area of a particular color region was calculated by the following equation:

[pixel count for color $(\mathrm{s}) \div$ pixel count for entire leaf] $\times 100 \%$

All plants were dried in a soil-drying room and shoot weight was noted.

There were four blocks of each treatment in this experiment. Each treatment was replicated on an individual bench with either a shade structure covering plants or plants grown on a non-shaded portion of the bench. There were two subsamples (plants) of each cultivar for each block for a total of eight plants of each cultivar for each 
treatment. Plants were arranged in a randomized complete block design. Data were tested for linear and quadratic trends using general linear models and Fisher's least significant difference in SAS (version 9.1). $R^{2}$ values were used to determine whether a linear or quadratic model was appropriate for each variable tested. Probability values less than or equal to 0.05 were considered statistically significant.

\section{Results and discussion}

Both 'Kong Red' and 'Wizard Coral Sunrise' coleus were larger when grown under a higher DLI. Plants had greater shoot dry weight, and both cultivars showed 4.2 -fold increases in shoot dry weight as DLI increased from 2.9 to $10.0 \mathrm{~mol} \cdot \mathrm{m}^{-2} \cdot \mathrm{d}^{-1}$ (Fig. 1A). Mean shoot dry weight for 'Kong Red' was $1.85 \mathrm{~g}\left(2.9 \mathrm{~mol} \cdot \mathrm{m}^{-2} \cdot \mathrm{d}^{-1}\right)$ and $7.7 \mathrm{~g}\left(10.0 \mathrm{~mol} \cdot \mathrm{m}^{-2} \cdot \mathrm{d}^{-1}\right)$ and for 'Wizard Coral Sunrise' was 1.6 and 6.5 $\mathrm{g}$, for plants grown under 2.9 and 10.0 $\mathrm{mol} \cdot \mathrm{m}^{-2} \cdot \mathrm{d}^{-1}$, respectively.

Total shoot height and maximum plant width of 'Kong Red' and 'Wizard Coral Sunrise' coleus were greater under higher DLIs (Fig. IB and $\mathrm{IC}$ ). This trend became apparent during weekly height measurements as early as Week 3 for 'Wizard Coral Sunrise' and Week 4 for 'Kong Red' (data not shown). Significant trends in plant width were observed as early as Weeks 2 and 3 in 'Wizard Coral Sunrise' and 'Kong Red', respectively (data not shown). 'Kong Red' coleus showed a positive linear correlation with DLI for final measures of both shoot height and plant width; plants grown under the highest DLI were $25 \%$ taller and $21 \%$ wider than those grown under the lowest DLI. 'Wizard Coral Sunrise' shoot height and plant width at harvest increased quadratically among the treatments. According to mean separation analysis, there was no difference in shoot height or plant width between the two highest DLIs $\left(5.8\right.$ and $\left.10.0 \mathrm{~mol} \cdot \mathrm{m}^{-2} \cdot \mathrm{d}^{-1}\right)$. 'Wizard Coral Sunrise' coleus grown under 5.8 or $10.0 \mathrm{~mol} \cdot \mathrm{m}^{-2} \cdot \mathrm{d}^{-1}$ of light were $22 \%$ taller and $18 \%$ wider compared with those grown under the lowest DLI (Fig. 1B and 1C).

Not all bedding plants grow taller and wider when grown under more light. Faust et al. (2005) conducted a similar study in which eight different bedding plants were grown under DLIs ranging from 5 to 43
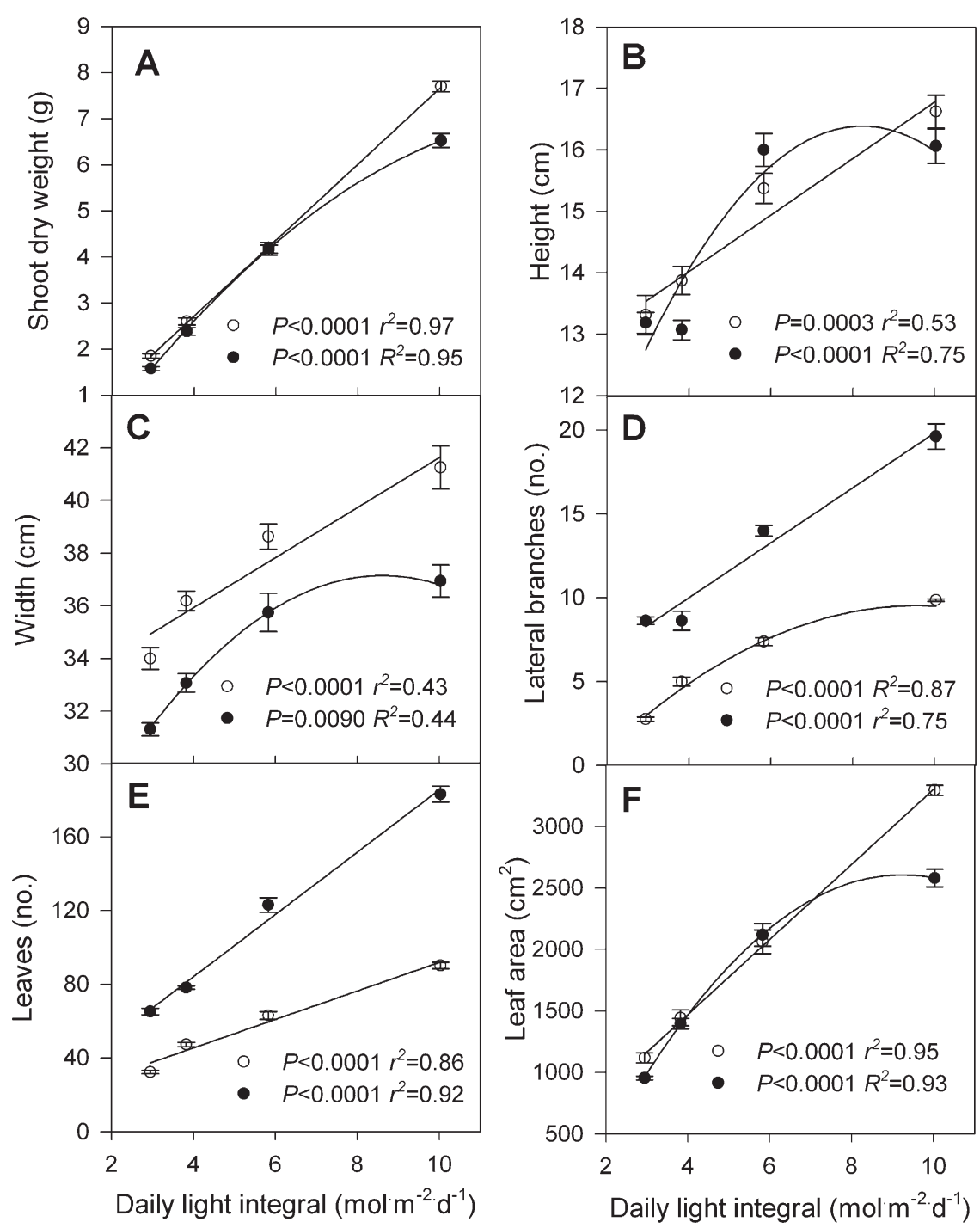

Fig. 1. Influence of daily light integral (DLI) on 'Kong Red' $(\bigcirc)$ and 'Wizard Coral Sunrise' $(\bullet$ ) coleus: (A) shoot dry weight, (B) height, (C) widest width, (D) number of lateral branches, (E) number of leaves, and (F) leaf area after 8 weeks. Data represent the mean of four replications with bars representing SE; $1 \mathrm{~g}=0.0353 \mathrm{oz}$, $1 \mathrm{~cm}=0.3937$ inch, $1 \mathrm{~cm}^{2}=0.1550$ inch $^{2}$.

$\mathrm{mol} \cdot \mathrm{m}^{-2} \cdot \mathrm{d}^{-1}$. They found that only one, african marigold (Tagetes erecta 'American Antigua Orange'), showed an increase in height with more light through all DLIs examined. Both ageratum (Ageratum houstonianaum 'Hawaii White') and petunia (Petunia Xhybrida 'Apple Blossom') were shorter under higher DLIs. 'Vodka Cocktail' begonia, salvia (Salvia coccinea 'Lady in Red'), and others showed an initial increase in height up to a certain DLI and were shorter at higher DLIs (Faust et al., 2005). 'Wizard Coral Sunrise' coleus appears to be approaching saturation levels in the highest DLI provided in this study. On the other hand, a linear increase in height in 'Kong Red' plants indicates that these may have become taller if plants were grown at light levels higher than $10.0 \mathrm{~mol} \cdot \mathrm{m}^{-2} \cdot \mathrm{d}^{-1}$. The possibility that 'Kong Red' may benefit from more light and 'Wizard Coral Sunrise' may have reached saturation is supported by the findings of Stack (2009), where 'Kong Red' was considered one of the sun-tolerant cultivars and 'Wizard Coral Sunrise' was noted as being better suited for shade.

Plants had more lateral branching at higher light levels (Fig. ID). Under $10.0 \mathrm{~mol} \cdot \mathrm{m}^{-2} \cdot \mathrm{d}^{-1}$, 'Kong Red' had 3.6 times as many branches and 'Wizard Coral Sunrise' more than twice as many branches as those grown under the $2.9-\mathrm{mol} \cdot \mathrm{m}^{-2} \cdot \mathrm{d}^{-1}$ regime. Of the two cultivars, only 'Wizard Coral 
Sunrise' produced secondary branching, which was observed only at the highest two light levels (data not shown). Higher light levels often increase branching (Faust, 2003). Similar increases in lateral branching were observed in petunia, ageratum, chrysanthemum (Dendranthema $\times$ grandiflorum), and cucumber (Cucumis sativus) (Faust et al., 2005; Warrington and Norton, 1991).

The two coleus cultivars also developed more leaves and greater leaf area as DLI increased (Fig. IE and F). Other researchers have observed similar responses in plant growth in a number of both high- and low-lightrequiring crops, including chrysanthemum, radish (Raphanus sativus), corn (Zea mays), cucumber, wax

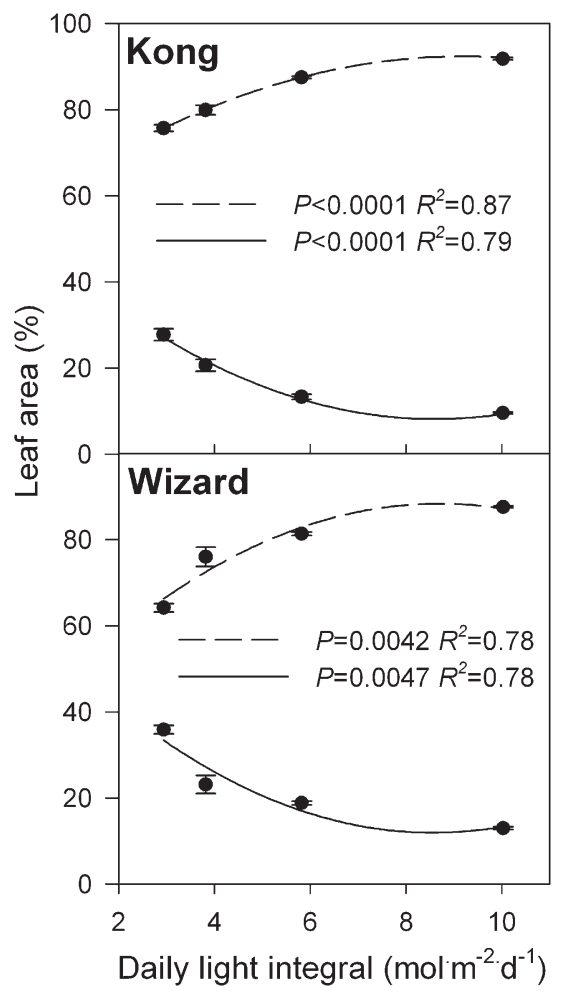

Fig. 2. The influence of daily light integral (DLI) on percent green (-) and non-green (- - - - ) leaf area of 'Kong Red' (Kong) and 'Wizard Coral Sunrise' (Wizard) coleus after 8 weeks. The percentage of each color was obtained from scanned images of the uppermost fully expanded leaves using an Adobe Photoshop graphics editor (CS2 version 9.0; Adobe Systems, San Jose, CA). The number of pixels of each color were divided by the total number of pixels for the entire leaf and subsequently multiplied by $\mathbf{1 0 0 \%}$. Data represent the mean of four replications with bars representing $S E$. begonia, english ivy, and cyclamen (Cyclamen persicum 'Metis Scarlet Red') (Nemali and van Iersel, 2004; Oh et al., 2009; Pennisi et al., 2005; Warrington and Norton, 1991).

The lowest possible light level for growing highly branched coleus that do not have reduced leaf area would be $10.0 \mathrm{~mol} \cdot \mathrm{m}^{-2} \cdot \mathrm{d}^{-1}$ for 'Kong Red'. 'Wizard Coral Sunrise' appeared to approach saturation for shoot dry weight, shoot height, plant width, branching, and leaf area and would be of greatest size when grown under $10.0 \mathrm{~mol} \cdot \mathrm{m}^{-2} \cdot \mathrm{d}^{-1}$. This confirms the minimum DLI for growing high-quality coleus of $9 \mathrm{~mol} \cdot \mathrm{m}^{-2} \cdot \mathrm{d}^{-1}$ (Verkbert et al., 2004) and is half as high as the maximum recommended DLI. Comparing this to DLI maps of the United States (Korczynski et al., 2002), it would be possible to grow coleus without supplemental lighting in all states, including the northeastern United States, during the spring production period (February through May) as long as greenhouse infrastructure does not impede light to reduce DLI to levels below 10 $\mathrm{mol} \cdot \mathrm{m}^{-2} \cdot \mathrm{d}^{-1}$.

For a highly variegated plant like coleus, it is important to consider not only morphology but also how DLI impacts foliar coloration. Both cultivars showed significant changes in leaf coloration in response to various DLIs (Figs. 2 and 3). For the purposes of this study, the term variegation refers to the relative amount of non-green leaf area per leaf. Leaves of both cultivars had less variegation when grown under lower DLIs. In other words, plants exposed to lower DLIs had a greater amount of green area per leaf. Increased variegation under higher light levels has also been observed in english ivy, pothos, and cast iron plant (Nam et al., 1997; Pennisi et al., 2005; Stamps, 1995).

The type of variegation observed in coleus is most likely due to nonclonal physiological changes in pigment concentration (S. Pennisi, personal communication). Anthocyanins are the colored flavanoid pigments responsible for much of the red coloration observed in coleus and a number of other ornamental crops (Beckwith et al., 2004; Lamprecht et al., 1975; Oren-Shamir and LeviNissim, 1997). It has been reported that the concentration of anthocyanins in smokebush (Cotinus coggygria
'Royal Purple') and cultivars of purple fountain grass (Pennisetum setaceum 'Rubrum' and 'Red Riding Hood') is greater under higher light conditions (Beckwith et al., 2004; Oren-Shamir and Levi-Nissim, 1997). The relative amount of burgundy in both 'Wizard Coral Sunrise' and 'Kong Red' increased quadradically with increasing DLI $\left(P=0.0007\right.$ and $0.0001 ; R^{2}=$ 0.67 and 0.90 , for 'Wizard Coral Sunrise' and 'Kong Red', respectively).

In both coleus cultivars, less green variegation and more burgundy would be desirable since plants are typically grown for their vividly colored foliage. For both cultivars, the percentage of non-green area approached saturation at $5.8 \mathrm{~mol} \cdot \mathrm{m}^{-2} \cdot \mathrm{d}^{-1}$. However, the amount of burgundy ('Kong Red') and coral ('Wizard Coral Sunrise') coloration was low enough that plants were considered of low quality when they were grown at light levels below $5.8 \mathrm{~mol} \cdot \mathrm{m}^{-2} \cdot \mathrm{d}^{-1}$.

\section{Conclusions}

Highly variegated 'Kong Red' and 'Wizard Coral Sunrise' coleus may be grown at light levels as low as $5.8 \mathrm{~mol} \cdot \mathrm{m}^{-2} \cdot \mathrm{d}^{-1}$. Greenhouse growers

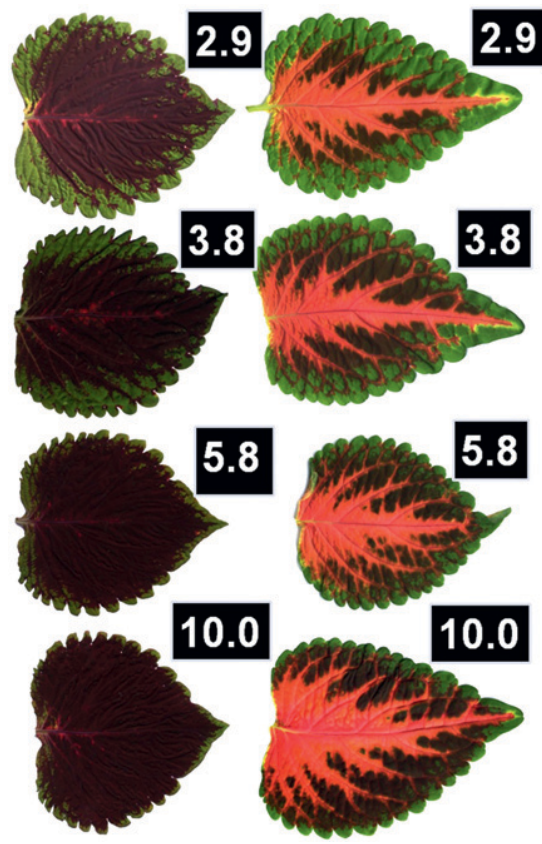

Fig. 3. Scanned images of the uppermost fully expanded leaves of 'Kong Red' (left) and 'Wizard Coral Sunrise' (right) coleus grown under four different daily light integrals (DLIs) ranging from 2.9 to 10.0 $\mathrm{mol} \cdot \mathrm{m}^{-2} \cdot \mathrm{d}^{-1}$ for 8 weeks. 
could produce these cultivars of coleus in all regions of the United States in February through May without providing supplemental lighting. For larger, more fully branched plants, particularly for 'Kong Red', plants should be grown under a minimum of $10.0 \mathrm{~mol} \cdot \mathrm{m}^{-2} \cdot \mathrm{d}^{-1}$ and additional lighting may further increase plant size and branching.

\section{Literature cited}

Armitage, A.M. 2001. Armitage's manual of annuals, biennials, and half-hardy perennials. Timber Press, Portland, OR.

Beckwith, A.G., Y. Zhang, N.P. Seeram, A.C. Cameron, and M.G. Nair. 2004. Relationship of light quantity and anthocyanin production in Pennisetum setaceum cvs. Rubrum and Red Riding Hood. J. Agr. Food Chem. 52:456-461.

Fausey, B.A., R.D. Heins, and A.C. Cameron. 2005. Daily light integral affects flowering and quality of greenhousegrown Achillea, Gaura, and Lavandula. HortScience 40:114-118.

Faust, J.E. 2003. Light, p. 71-84. In: D. Hamrick (ed.). Ball redbook, vol. 2: Crop production. 17th ed. Ball Publishing, Batavia, IL.

Faust, J.E., V. Holcombe, N.C. Rajapakse, and D.R. Layne. 2005. The effect of daily light integral on bedding plant growth and flowering. HortScience 40:645-649.

Fisher, P.R. and E. Runkle. 2004. Managing lighting in the greenhouse: Why is it important? p. 9-17. In: P.R. Fisher and E. Runkle (eds.). Lighting up profits: Un- derstanding greenhouse lighting. Meister Media Worldwide, Willoughby, $\mathrm{OH}$.

Korczynski, P.C., J. Logan, and J.E. Faust. 2002. Mapping monthly distribution of daily light integrals across the contiguous United States. HortTechnology 12:12-16.

Lamprecht, W.O., H. Applegate, and R.D. Powell. 1975. Pigments of Coleus blumei. Phyton 33:157-163.

Li, Q., C. Jianjun, D.B. McConnell, and R.J. Henny. 2007. A simple and effective method for quantifying leaf variegation. HortTechnology 17:285-288.

Nam, Y.K., B.H. Kwack, and H.R. Kwack. 1997. Different extents of leaf variegation in Epipremnum aureum as influenced by different light levels. J. Korean Soc. Hort. Sci. 38:537-540.

Nemali, K.S. and M.W. van Iersel. 2004. Acclimation of wax begonia to light intensity: Changes in photosynthesis, respiration, and chlorophyll concentration. J. Amer. Soc. Hort. Sci. 129:745-751.

Oh, W., I.H. Cheon, K.S. Kim, and E. Runkle. 2009. Photosynthetic daily light integral influences flowering time and crop characteristics of Cyclamen persicum. HortScience 44:341-344.

Oren-Shamir, M. and A. Levi-Nissim. 1997. UV-light effect on the leaf pigmentation of Cotinus coggygria 'Royal Purple.' Sci. Hort. 71:59-66.

Pennisi, S., M.W. van Iersel, and S.E. Burnett. 2005. Photosynthetic irradiance and nutrition effects on growth of English ivy in subirrigation systems. HortScience 40:1740-1745.
Pramuk, L.A. and E.S. Runkle. 2005. Photosynthetic daily light integral during the seedling stage influences subsequent growth and flowering of Celosia, Impatiens, Salvia, Tagetes, and Viola. HortScience 40:1336-1339.

Rogers, R. and R. Hartlage. 2008. Coleus: Rainbow foliage for containers and gardens. Timber Press, Portland, OR.

Shen, G.W. and J.G. Seeley. 1983. The effect of shading and nutrient supply on variegation and nutrient content of variegated cultivars of Peperomia obtusifolia. J. Amer. Soc. Hort. Sci. 108:429-433.

Stack, L.B. 2009. Field trials assessing sunscald and flowering of coleus cultivars. Univ. Mass. Floral Notes 21:4-8.

Stamps, R.H. 1995. Effects of shade level and fertilizer rate on yield and vase life of Aspidistra elatior 'Variegata' leaves. J. Environ. Hort. 13:137-139.

Verkbert, H., R. Heins, and T. Blom. 2004. Supplemental lighting on potted plants, p. 72-78. In: P.R. Fisher and E. Runkle (eds.). Lighting up profits: Understanding greenhouse lighting. Meister Media Worldwide, Willoughby, $\mathrm{OH}$.

Vladimirova, S.V., D.B. McConnell, M.E. Kane, and R.W. Henley. 1997. Morphological plasticity of Dracaena sanderana 'Ribbon' in response to four light intensities. HortScience 32:1049-1052.

Warrington, I.J. and R.A. Norton. 1991. An evaluation of plant growth and development under various daily quantum integrals. J. Amer. Soc. Hort. Sci. 116: 544-551. 